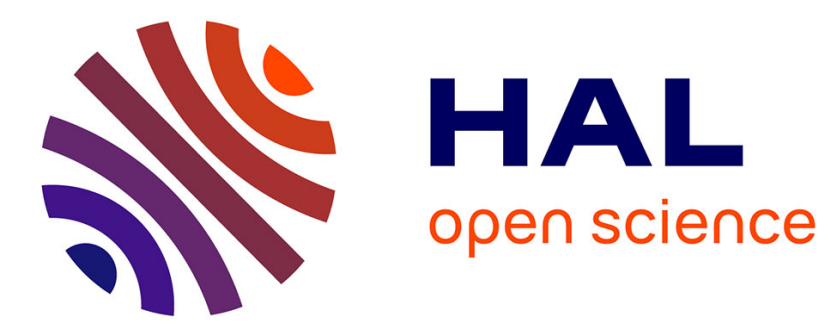

\title{
Recent Representative Advances on the Synthesis and Reactivity of N -heterocyclic-carbene-supported Zinc Complexes
}

\author{
David Specklin, Christophe Fliedel, Samuel Dagorne
}

\section{- To cite this version:}

David Specklin, Christophe Fliedel, Samuel Dagorne. Recent Representative Advances on the Synthesis and Reactivity of N -heterocyclic-carbene-supported Zinc Complexes. Chemical Record, 2021, 21 (5), pp.1130-1143. 10.1002/tcr.202100041 . hal-03204158

\section{HAL Id: hal-03204158 \\ https://hal.science/hal-03204158}

Submitted on 21 Apr 2021

HAL is a multi-disciplinary open access archive for the deposit and dissemination of scientific research documents, whether they are published or not. The documents may come from teaching and research institutions in France or abroad, or from public or private research centers.
L'archive ouverte pluridisciplinaire HAL, est destinée au dépôt et à la diffusion de documents scientifiques de niveau recherche, publiés ou non, émanant des établissements d'enseignement et de recherche français ou étrangers, des laboratoires publics ou privés. 
Recent Representative Advances on the synthesis and reactivity of $\mathrm{N}$ heterocyclic-carbene-supported Zinc Complexes

David Specklin, Christophe Fliedel and Samuel Dagorne*

Institut de Chimie (UMR CNRS 7177), Université de Strasbourg, 4, rue Blaise Pascal, 67000 Strasbourg, France.

Dedicated to Professor Pierre H. DIXNEUF for his outstanding contributions to organometallic chemistry and homogeneous catalysis.

*Email : dagorne@unistra.fr 


\begin{abstract}
The present account reviews the most recent noteworthy developments on the synthesis, structure and catalytic applications of Zn-NHC species, a class of complexes that have attracted attention over the past five to ten years due to their enhanced robustness and hydrolytic stability versus classical $\mathrm{Zn}$ organometallics. In particular, thanks to NHC stabilization, access to unprecedented $\mathrm{Zn}$ species were recently achieved, including twocoordinate $\mathrm{Zn}(\mathrm{II})$ organocations and thermally stable molecularly well-defined Zn hydride species, opening the way to effective Zn-mediated hydro-silylation/-boration catalysis of various unsaturated substrates under mild conditions. The potential of NHC-Zn species for the stabilization of unprecedented $\mathrm{Zn}$ species and use in various catalytic applications is only emerging and the vast array of readily available NHC structures should promote future developments of the field.
\end{abstract}

Keywords: Zinc, $N$-heterocyclic carbene, Lewis acids, catalysis

\title{
For Tables of Contents Only
}

\section{Applications in catalysis}

- Reduction of unsaturated substrates (including $\mathrm{CO}_{2}$ )

- Alkylation

- Cross-coupling catalysis

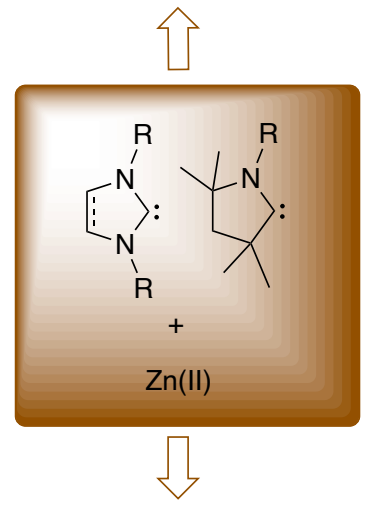

Novel classes of $\mathrm{Zn}(\mathrm{II})$ species

- Two-coordinate Zn(II) organocations

- Well-defined Zn(II) hydride species 


\section{Introduction}

Over the past twenty years, $N$-heterocyclic carbenes (NHCs) have become an ubiquitous class of ligands for coordination to various transition/main group metal/heteroelement centers, which has led to numerous and diversified developments across chemical science, most notably in the areas of metal-mediated homogeneous catalysis, organometallic chemistry and related fundamental reactivity. ${ }^{1,2,3,4}$ The widespread use and success of NHC ligands take their source in the exceptional electronic properties (strong $\sigma$-donor) and steric tunability (primarily through the nature of the N-R group) of such entities, combined with well-established straightforward synthetic procedures to access NHCs. ${ }^{5,6,7,8} \mathrm{NHC}$ coordination to various metal centers/heteroatoms (from carbo- to oxo-philic metals/heteroatoms) frequently provide unprecedented stabilization of the resulting organometallic fragments, which are features of interest for use in catalysis and the characterization of highly reactive organometallics. ${ }^{9}, 10,11,12,13,14,15$ Additionally, recent and ongoing research efforts on the design/modifications of NHC heterocyclic backbone have already expanded the electronic/steric tunability (relative to those of classical Arduengo-type carbenes), and thus the potential scope of applications of these carbene ligands. ${ }^{8,16}$

Zn-based species are notoriously known and have found widespread use as reagents for stoichiometric and catalytic chemical transformations, ranging from their use as Lewis acid catalysts to their frequent employment as alkylating agents for unsaturated substrates functionalization. ${ }^{17}$ Given that $\mathrm{Zn}$ is a cheap, environmentally benign and readily available metal source, Zn-based species, in particular well-defined Zn organometallics, have recently attracted increased attention for use in small molecules functionalization/activation. ${ }^{18}$ Since the first report on a NHC-stabilized Zn(II) species by Arduengo in $1993,{ }^{19} \mathrm{NHC}-\mathrm{Zn}$ species, thanks to the remarkable kinetic stability of the $\mathrm{Zn}$-Carbene bond, have played a major role in the 
recent advancements of $\mathrm{Zn}$ organometallic chemistry, allowing access to unprecedented welldefined and highly reactive $\mathrm{Zn}$ entities..$^{20,21}$ In addition to the structural interest of a number of NHC-Zn species recently reported, applications of NHC-Zn species in catalysis now spans from their use in alkyne dehydroboration/diboration, allylic alkylation, alkyne/alkene $/ \mathrm{CO}_{2}$ hydrosilylation to polymerization catalysis of polar monomers. The present account highlights the most recent (5 to 10 years) noteworthy advances, including those from our lab, on the synthesis and reactivity studies of Zn complexes supported by NHCs.

\section{Neutral NHC-Zn alkyl/aryl/halide complexes and related derivatives}

$\mathrm{ZnX}_{2}(\mathrm{X}=\mathrm{Me}$, Et, halide) species are widespread reagents in organic chemistry as alkylating/reducing and Lewis acidic reagents/catalysts, but are typically highly moisturesensitive. NHC adducts of the type $\left[(\mathrm{NHC}) \mathrm{ZnX}_{2}\right](\mathrm{X}=\mathrm{Me}$, Et, halide) constitute easier-tohandle $\mathrm{ZnX}_{2}$ sources and are thus of potential interest for various stoichiometric and catalytic organic reactions. Adducts of the type $\left[(\mathrm{NHC}) \mathrm{ZnX}_{2}\right]$ are most frequently prepared by reaction of free $\mathrm{NHC}$ with $\mathrm{ZnX}_{2}$ and afford monomeric $\left(\left[(\mathrm{NHC}) \mathrm{ZnX}_{2}\right]\right)$ or dimeric $\left(\left[(\mathrm{NHC}) \mathrm{ZnX}_{2}\right]_{2}(\mathbf{1 -}\right.$ 3, Figure 1). Over the recent years, a number of monomeric NHC-bearing Zn di-alkyl/-aryl/alkoxide derivatives were reported ${ }^{22,23,24,25}$ and were primarily used as polymerization catalysts (vide infra). ${ }^{21,22,26}$<smiles>[R]N1C=CN([R7])C1[Te]P</smiles>

$$
\mathrm{R}=\text { alkyl, aryl }
$$$$
\mathrm{R}^{\prime}=\mathrm{Me}, \mathrm{Et},{ }^{\mathrm{t}} \mathrm{Bu}
$$
1

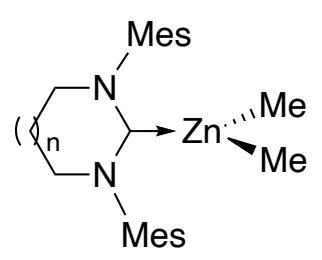

$\mathrm{n}=1,2$

2<smiles>[R]N1C=CN([R])C1[Z10]([Y])([X])[Z]</smiles>

$X=$ halide

3

Figure 1. Monomeric $\left[(\mathrm{NHC}) \mathrm{ZnX}_{2}\right]$ and dimeric $\left[(\mathrm{NHC}) \mathrm{ZnX}_{2}\right]_{2}$ species 
Mixed alkyl chloro derivatives (4, Scheme 1) are also accessible via a direct protonolysis reaction between $\mathrm{ZnR}_{2}$ and the corresponding imidazolium chloride, and were readily converted dimeric NHC-Zn alkoxides 5. ${ }^{27,28}$

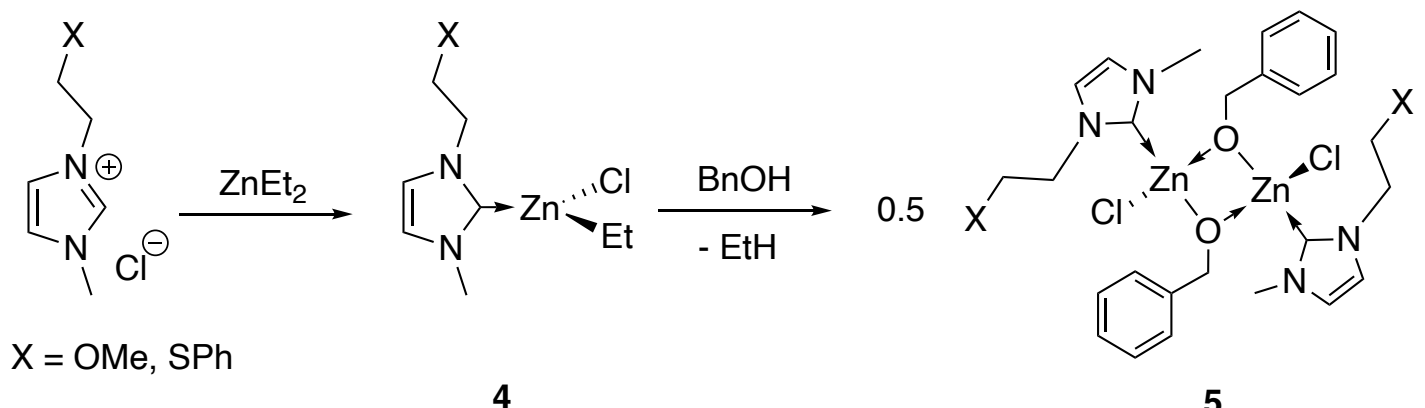

Scheme 1. Synthesis of NHC-Zn complexes 4 and 5

Species of type $\mathbf{5}$ were shown to be highly effective ring-opening polymerization (ROP) catalysts of lactide (TOF up to $500 \mathrm{~h}^{-1}$ at room temperature), a bio-sourced monomer, for the production of well-defined PLA, a biodegradable polyester with numerous applications and of growing industrial importance (Scheme 2). ${ }^{29}$ Likewise, trimethylenecarbonate (TMC), a cyclic carbonate available in a few synthetic steps from glycerol, ${ }^{30}$ is also efficiently polymerized to yield narrow disperse polytrimethylenecarbonate (PTMC), a biodegradable material currently used on the biomedical area (Scheme 2). ${ }^{31}$ These ROPs proceed via initial monomer insertion/ring-opening into the $\mathrm{Zn}-\mathrm{OBn}$ bond and subsequent chain growth, allowing access to chain-length-controlled poly-esters/-carbonates. All data suggest the non-involvement of the NHC moiety and thus with a stable Zn-NHC bond as the ROP proceeds.

$n$<smiles>C[C@@H]1OC(=O)[C@H](C)OC1=O</smiles><smiles>CC(O)C(=O)Oc1ccccc1</smiles>

ROP

PLA catalysis

$\mathrm{n}$<smiles>O=C1OCCCO1</smiles>

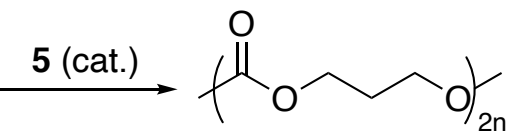

PTMC 
Scheme 2. ROP catalysis mediated by NHC-Zn benzyloxide species 5 for the production of biodegradable polyesters and polycarbonates.

Interestingly, NHC-Zn species $\mathbf{4}$ and $\mathbf{5}$ also catalyze the controlled degradation of PLA to methyl lactate at room temperature in the presence of a large excess of $\mathrm{MeOH}$ (100 equiv vs. 4 or 5, Scheme 3). Remarkably, control experiments indicate the Zn-NHC bond essentially retains its integrity under such conditions, indicating the remarkable kinetic stability of the $\mathrm{Zn}-\mathrm{C}_{\text {carbene }}$ bond towards methanolysis. ${ }^{27}$<smiles>COC(=O)C(C)O</smiles>

PLA

Scheme 3. Controlled degradation of PLA mediated by NHC-Zn species $\mathbf{4}$ and $\mathbf{5}$

The robustness of $\left[(\mathrm{NHC}) \mathrm{ZnX}_{2}\right]$ species was also exploited for stoichiometric and catalytic $\mathrm{CO}_{2}$ functionalization/reduction. Thus, dimer [(IDipp) $\left.\mathrm{ZnCl}_{2}\right]_{2}$ was successfully used as catalyst for the efficient production of methylamines through methylation of secondary amines with $\mathrm{CO}_{2}$ and hydrosilanes (Scheme 4) ${ }^{32}$ The catalytic formation of $\mathrm{C}-\mathrm{N}$ bonds through the use of $\mathrm{CO}_{2}$, a cheap and renewable $\mathrm{C} 1$ source, along with an inexpensive metal source such as Zinc is of interest. For instance, a $\mathrm{N}$-methylaniline/ $\mathrm{PhSiH}_{3}$ mixture under $\mathrm{CO}_{2}$ (1 bar) may be quantitatively converted to $\mathrm{Me}_{2} \mathrm{NPh}\left(20 \mathrm{~h}, 100^{\circ} \mathrm{C}\right)$. The role of the NHC-Zn moiety appears crucial for the catalysis to proceed efficiently since commercial $\mathrm{ZnX}_{2}(\mathrm{X}=\mathrm{Cl}, \mathrm{Br})$ salts are much less effective catalysts. The reaction is proposed to occur via the formation of a formyl species, then hydrosilylated to the final product.

$$
\begin{aligned}
& \mathrm{CO}_{2}+\mathrm{RR}{ }^{\prime} \mathrm{NH}+\mathrm{R} \text { "SiH } \stackrel{3 \text { (cat.) }}{\longrightarrow} \mathrm{RR} \text { 'N-Me } \\
& R, R^{\prime}, R^{\prime \prime}=\text { alkyl, aryl }
\end{aligned}
$$

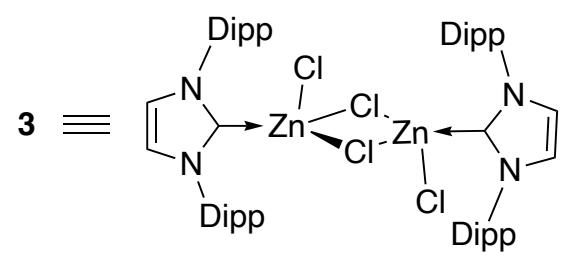


Scheme 4. Reductive methylation of secondary amines catalyzed by a $\mathrm{NHC}-\mathrm{ZnCl}_{2}$ species.

The reactivity of NHC-Zn adducts of the type $\left[\mathrm{Cp}^{*} \mathrm{Zn}\left(\mathrm{C}_{6} \mathrm{~F}_{5}\right)(\mathrm{NHC})\right](\mathbf{6}$, Scheme 5) with $\mathrm{CO}_{2}$ was also studied. ${ }^{33}$ Interestingly, the stoichiometric reaction of $\mathbf{6}$ with $\mathrm{CO}_{2}$ exclusively proceeds through insertion into the $\mathrm{C}_{\mathrm{Cp}^{*}}-\mathrm{Zn}$ bond to afford the corresponding mononuclear $\mathrm{Zn}$ carboxylate derivative 7 (Scheme 5), with thus the NHC-Zn moiety retaining its integrity. In the present system, $\mathrm{NHC}$ coordination is clearly beneficial since $\mathrm{CO}_{2}$ insertion proceeds much faster and under milder conditions than that of "base-free" $\left[\mathrm{Cp}^{*} \mathrm{Zn}\left(\mathrm{C}_{6} \mathrm{~F}_{5}\right)\right]$.

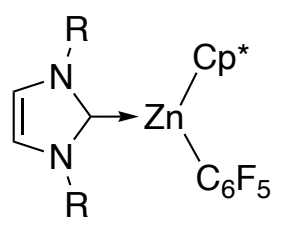<smiles>O=C(O)CBr</smiles>
RT $\mathrm{R}=t \mathrm{Bu}, \mathrm{Dipp}$, Mes

6

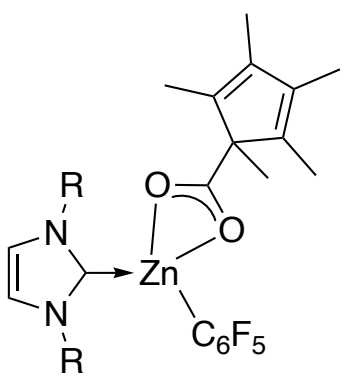

Scheme 5. $\mathrm{CO}_{2}$ insertion reactivity of NHC-Zn adducts of the type $\left[\mathrm{Cp}^{*} \mathrm{Zn}\left(\mathrm{C}_{6} \mathrm{~F}_{5}\right)(\mathrm{NHC})\right]$

Several $\left[(\mathrm{NHC}) \mathrm{ZnX}_{2}\right](\mathrm{X}=\mathrm{Cl}, \mathrm{Br})$ adducts were recently shown to catalyze the crosscoupling of diboron reagent $\mathrm{B}_{2}$ (pinacolate) 2 with alkyl/aryl halides (Scheme 5). ${ }^{34,35}$ Such catalysis, which proceeds at room temperature, is most efficient with IMes as the NHC source. The mechanism of such Zn-catalyzed borylation of alkyl/aryl halides is likely to go through a radical process based on experimental data.

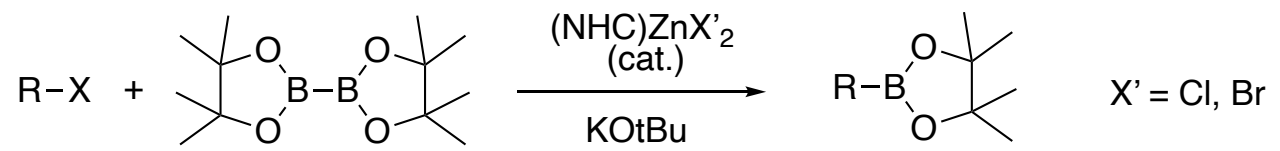

$$
\begin{aligned}
& \mathrm{R}=\text { alkyl, aryl } \\
& \mathrm{X}=\mathrm{Br}, \mathrm{I}
\end{aligned}
$$


Scheme 5. Alkyl/aryl halides cross-coupling catalysis mediated by NHC-stabilized Zn(II) dihalides.

Control experiments on the reactivity of ( $\mathrm{NHC}) \mathrm{ZnX}_{2}$ species with $\mathrm{B}_{2}$ (pinacolate) $)_{2}$ in the presence of ${ }^{t} \mathrm{BuOK}$ evidenced the limited stability of the NHC-Zn moiety under such conditions. Thus, the stoichiometric reaction between [(IMes) $\mathrm{ZnCl}_{2}$ ] with a $1 / 1 \mathrm{~B}_{2}$ (pinacolate) $)_{2}$ ${ }^{t} \mathrm{BuOK}$ mixture unexpectedly led to the isolation of the ring-expanded product 8 (Scheme 6), whose structure was confirmed through X-ray diffraction studies. ${ }^{34}$ The formation of $\mathbf{8}$, a compound that may be described as a di-carbenoid-type species, formally arises from $\mathrm{Zn}$ insertion into the $\mathrm{C}_{\text {carbene }} \mathrm{N}$ bond of a $\mathrm{NHC}$ while a $\mathrm{B}$ (pinacolate) group inserts in a similar manner in another NHC moiety.<smiles></smiles>

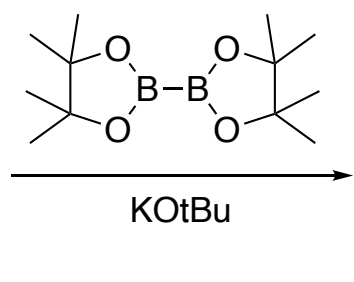

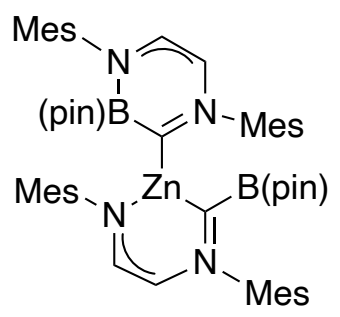

8

(isolated in low yield)

Scheme 6. Isolation of species 8 from the reaction of [(IMes) $\left.\mathrm{ZnCl}_{2}\right]$ with a (pin)B$\mathrm{B}(\mathrm{pin}) / \mathrm{tBuOK}$ mixture

Chelating ligand platforms incorporating a NHC group were also investigated for coordination to $\mathrm{Zn}(\mathrm{II})$ and led to advances in fundamental reactivity and $\mathrm{Zn}$-based catalysis. As noteworthy examples, the use of an anionic tridentate NHC-bis-oxazoline borate ligand for the stabilization of a rare example of well-defined $\mathrm{Zn}$ (II) peroxo derivative (9, Scheme 7), generated through an insertion reaction of $\mathrm{O}_{2}$ with the corresponding $\mathrm{Zn}-\mathrm{Et}$ precursor $\mathbf{8}^{36}$ Further, various (NHC)Zn supported by a chiral bidentate NHC-bearing ligand, such as $\mathbf{1 0}$ (Scheme 8), were demonstrated to be highly active catalysts for the enantioselective alkylation 
of allylic substrates (using $\mathrm{ZnEt}_{2}$ as an alkyl source) with an excellent regioselectivity ( $>98 \%$ ) and a good enantioselectivity (enantiomeric ratio: 82/18; Scheme 8). ${ }^{37}$ All experimental data are consistent with $\mathrm{Zn}(\mathrm{II})$ chelate $\mathbf{1 0}$ acting as a bifunctional catalyst: i.e. as a Lewis acid (with coordination of the allylic substrate to the $\mathrm{Zn}$ (II) center) and a Lewis base (with the coordination of the sulfonate function to $\mathrm{ZnEt}_{2}$ ), such cooperation being crucial to the activity and selectivity of the catalytic process.

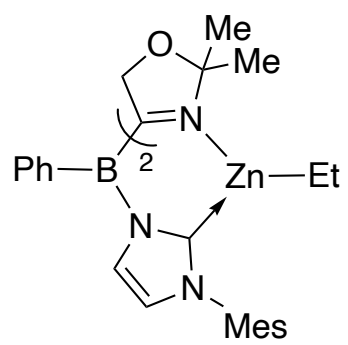

8

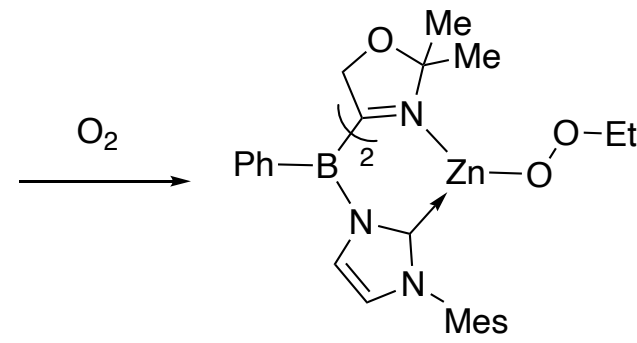

9

Scheme 7. $\mathrm{O}_{2}$ insertion reactivity of NHC-Zn ethyl chelate 8 to afford (NHC)Zn peroxide 9.<smiles>CCO[Po](OCC)OC/C=C/c1ccccc1</smiles><smiles>CCOC(=O)OCC</smiles>
er: $82 / 18$<smiles>CC[Z17]1([I-]F)OS(=O)(=O)c2ccccc2N2[C@@H](c3ccccc3)[C@H](c3ccccc3)N21</smiles>

10

Scheme 8. Allylic alkylation catalyzed by chiral NHC-supported Zn(II) species $\mathbf{1 0 .}$

\section{Low-coordinate NHC-stabilized Zn alkyl/aryl Cations}

The exceptional $\sigma$-donating of NHCs recently allowed the isolation and structural characterization of the first two-coordinate $\mathrm{Zn}(\mathrm{II})$ organocations. ${ }^{38}$ Thus, ionization of [(IDipp) $\left.\mathrm{ZnR}_{2}\right]$ adducts $(\mathrm{R}=\mathrm{Me}, \mathrm{Et})$ with $\left[\mathrm{Ph}_{3} \mathrm{C}\right]\left[\mathrm{B}\left(\mathrm{C}_{6} \mathrm{~F}_{5}\right)_{4}\right]$ led to the corresponding cations [(IDipp)Zn-R $]^{+}(\mathbf{1 1}$, Scheme 9) as stable two-coordinate $\mathrm{Zn}(\mathrm{II})$ cations. Derivatization of the Zn-alkyl cations of type 11 with $\mathrm{B}\left(\mathrm{C}_{6} \mathrm{~F}_{5}\right)_{3}$ quantitatively yielded the more electrophilic [(IDipp)Zn- $\left.\mathrm{C}_{6} \mathrm{~F}_{5}\right]^{+}$cation 12 (Scheme 9), also a thermally stable $\mathrm{Zn}(\mathrm{II})$ cation. Lewis acidity 
experimental estimation (using the Gutmann-Beckett method) of those cations agree with cation 12 being the most Lewis acidic of the series with a comparable Lewis acidity to landmark $\mathrm{B}\left(\mathrm{C}_{6} \mathrm{~F}_{5}\right)_{3}$. Yet, the DFT-estimated Fluoride Ion Affinity (FIA, calculated in the gas phase) of cation 12 suggests a stronger Lewis acidity than $\mathrm{B}\left(\mathrm{C}_{6} \mathrm{~F}_{5}\right)_{3}$. The molecular structures of cations 11 and 12, depicted in Figure 2 in the case of 12, display a nearly linear $C_{\text {carbene }}-\mathrm{Zn}-\mathrm{C}$ array (angles close to $180{ }^{\circ} \mathrm{C}$ ). When crystallized from $\mathrm{CH}_{2} \mathrm{Cl}_{2}$, the solid state data for salts [1112] $\left[\mathrm{B}\left(\mathrm{C}_{6} \mathrm{~F}_{5}\right)_{4}\right]$ agree with discrete $[(\mathrm{IDipp}) \mathrm{Zn}-\mathrm{R}]^{+}$and $\left[\mathrm{B}\left(\mathrm{C}_{6} \mathrm{~F}_{5}\right)_{4}\right]^{-}$ions with no apparent cation/anion short contacts. Yet, in solution $\left(\mathrm{CD}_{2} \mathrm{Cl}_{2}, \mathrm{RT}\right),{ }^{1} \mathrm{H}$ and ${ }^{19} \mathrm{~F}$ DOSY NMR data for [(IDipp) $\mathrm{Zn}-\mathrm{Me}]\left[\mathrm{B}\left(\mathrm{C}_{6} \mathrm{~F}_{5}\right)_{4}\right]$ are consistent with weakly interacting anions and cations, while data for [(IDipp) $\left.\mathrm{Zn}-\mathrm{C}_{6} \mathrm{~F}_{5}\right]\left[\mathrm{B}\left(\mathrm{C}_{6} \mathrm{~F}_{5}\right)_{4}\right]$, which bears a more electrophilic but also slightly more sterically crowded $\mathrm{Zn}(\mathrm{II})$ center, agree with dissociated anions under the studied conditions.

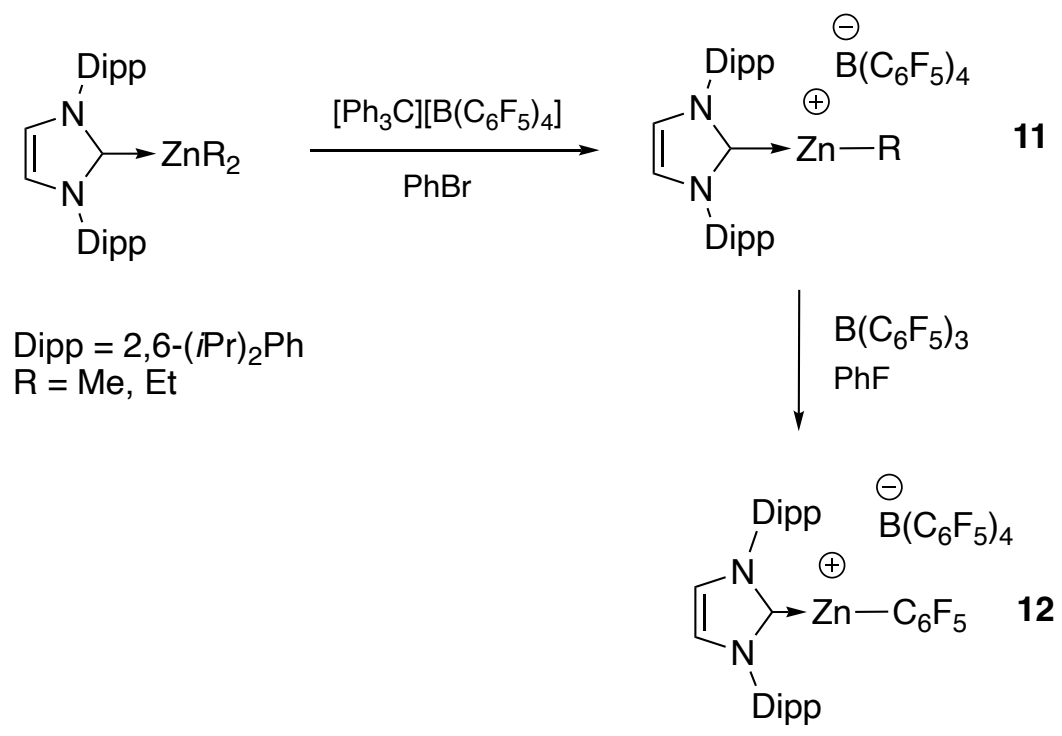

Scheme 9. Synthesis of two-coordinate NHC-Zn cations 11 and $\mathbf{1 2 .}$ 


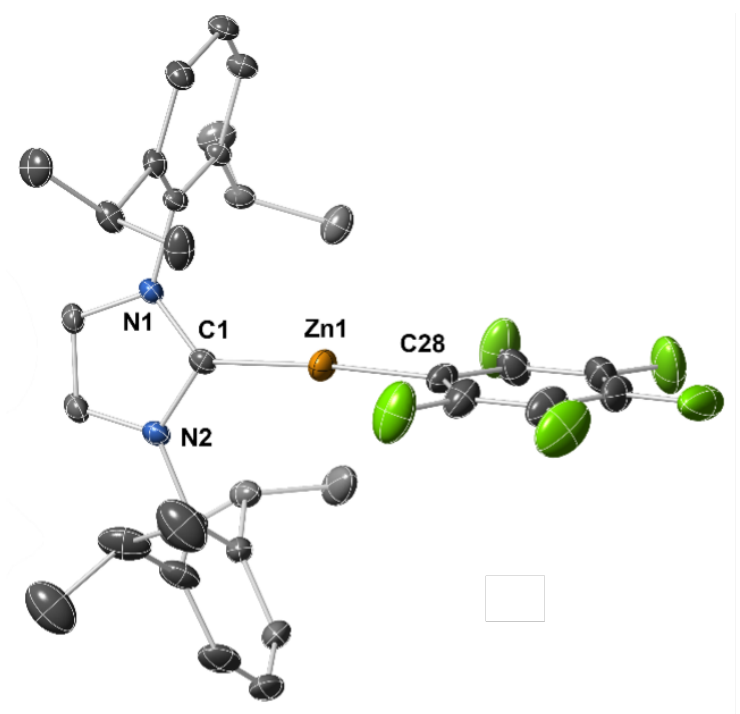

Figure 2. Molecular structure (ORTEP view) of cation 12.

Thanks to its Lewis acidity, two-coordinate cation $\mathbf{1 2}$ is an effective catalyst for alkene and alkyne hydrosilylation. Cation 12 catalyzes 1-hexene hydrosilylation (with $\mathrm{H}-\mathrm{SiEt}_{3}$ ) at RT to selectively afford $\mathrm{Et}_{3} \mathrm{Si}_{-} \mathrm{C}_{6} \mathrm{H}_{13}$ through an anti-addition of $\mathrm{HSiEt}_{3}$ to the alkene moiety (Scheme 10). Likewise, it readily mediates 1-octyne hydrosilylation to selectively yield the corresponding $Z$-isomer vinylsilane product (Scheme 10). These hydrosilylations likely proceed through a Lewis-acid-type catalysis similar to those documented for strong group 13 element Lewis acids such as $\mathrm{B}\left(\mathrm{C}_{6} \mathrm{~F}_{5}\right)_{3} .{ }^{39}$

$$
\begin{gathered}
=\mathrm{C}_{4} \mathrm{H}_{9}+\mathrm{HSiEt}_{3} \underset{\mathrm{RT}, \mathrm{CH}_{2} \mathrm{Cl}_{2}}{\stackrel{\mathbf{1 2}(5 \% \mathrm{~mol} .)}{\longrightarrow}} \mathrm{Et}_{3} \mathrm{Si} \sim \mathrm{C}_{4} \mathrm{H}_{9} \\
\equiv \mathrm{C}_{6} \mathrm{H}_{13}+\mathrm{HSiEt}_{3} \underset{\mathrm{RT}, \mathrm{CH}_{2} \mathrm{Cl}_{2}}{\stackrel{\mathbf{1 2}(5 \% \mathrm{~mol} .)}{\longrightarrow}} \underset{\mathrm{SiEt}_{3}}{\stackrel{\mathrm{C}_{6} \mathrm{H}_{13}}{\longrightarrow}}
\end{gathered}
$$

Scheme 10. Alkene and alkyne hydrosilylation catalysis mediated by cation $\mathbf{1 2}$.

Interestingly, upon heating, cation $\mathbf{1 2}$ is also an efficient catalyst for $\mathrm{CO}_{2}$ hydrosilylation to selectively afford methane along siloxane by-products (Scheme 11). At best, cation 12 (0.5 mol \%) quantitatively converted a $\mathrm{HSiEt}_{3} / \mathrm{CO}_{2}$ mixture to methane within $23 \mathrm{~h}$ at $90{ }^{\circ} \mathrm{C}$ in $\mathrm{PhBr}$, 
reflecting the effectiveness and robustness of such NHC-stabilized Zn electrophiles. In the case of the less Lewis acidic $\mathrm{Zn}$ cations of type 11, $\mathrm{CO}_{2}$ hydrosilylation catalysis under identical reaction conditions led to the selective formation of the methanol-equivalent methoxy product $\mathrm{MeO}-\mathrm{SiEt}_{3}$. As a comparison, $\mathrm{Et}_{2} \mathrm{O}$-supported $\mathrm{Zn}-\mathrm{R}^{+}$cations of the type $\left(\mathrm{Et}_{2} \mathrm{O}\right)_{3} \mathrm{Zn}-\mathrm{R}^{+}(\mathrm{R}=$ $\mathrm{Me}, \mathrm{Et}, \mathrm{C}_{6} \mathrm{~F}_{5}$ ) exhibit no alkene, alkyne and $\mathrm{CO}_{2}$ hydrosilylation catalytic activity under similar reaction conditions.

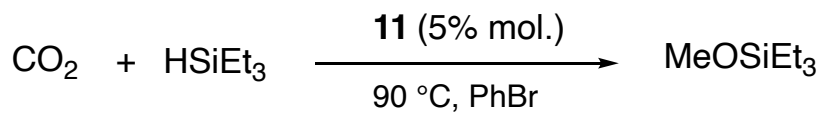

$$
\begin{aligned}
& \mathrm{CO}_{2}+\mathrm{HSiEt}_{3} \underset{90^{\circ} \mathrm{C}, \mathrm{PhBr}}{\stackrel{12(0.5 \% \mathrm{~mol} .)}{\longrightarrow}} \mathrm{CH}_{4}
\end{aligned}
$$

Scheme 11. $\mathrm{CO}_{2}$ hydrosilylation catalysis performed by NHC-Zn cations 11 and 12.

Bis-NHC three-coordinate $\mathrm{Zn}(\mathrm{II})$ organocations such as $\mathbf{1 3}$ and $\mathbf{1 4}$ (Scheme 12) were also reported and illustrate the adaptability of NHC coordination to Zn(II) for improved stability and well-defined reactivity. ${ }^{40}$ Thus, the initially prepared tris-organyl Zn(II) cation [(IDipp) ${ }_{2} \mathrm{Zn}-$ $\mathrm{Me}]^{+}(\mathbf{1 3})$, a severely crowded species bearing two C2-bonded NHC ligands (Figure 3), readily isomerizes in the presence of a Lewis base such as THF to [(IDipp)(aIDipp)Zn-Me $]^{+}(\mathbf{1 4}$, Scheme 12 and Figure 3), in which one of the NHC ligands is now C4/C5 bonded to the $\mathrm{Zn}$ (II) center. Steric relief for improved stability is clearly the driving force of the isomerization of $\mathbf{1 3}$ to $\mathbf{1 4}$, as was further rationalized by DFT calculations.

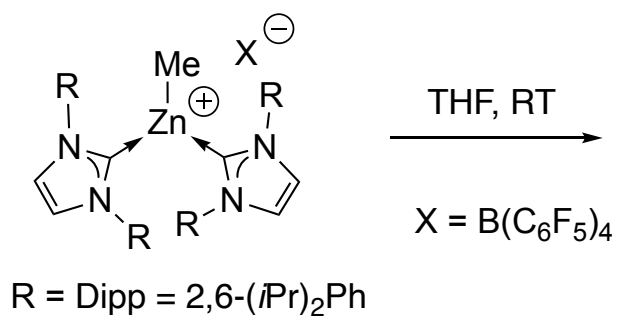

13

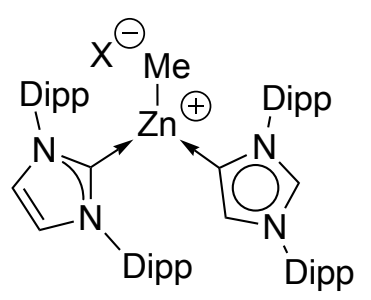

14

Scheme 12. THF-catalyzed isomerization of bis-NHC Zn(II) cation 13 to 14. 

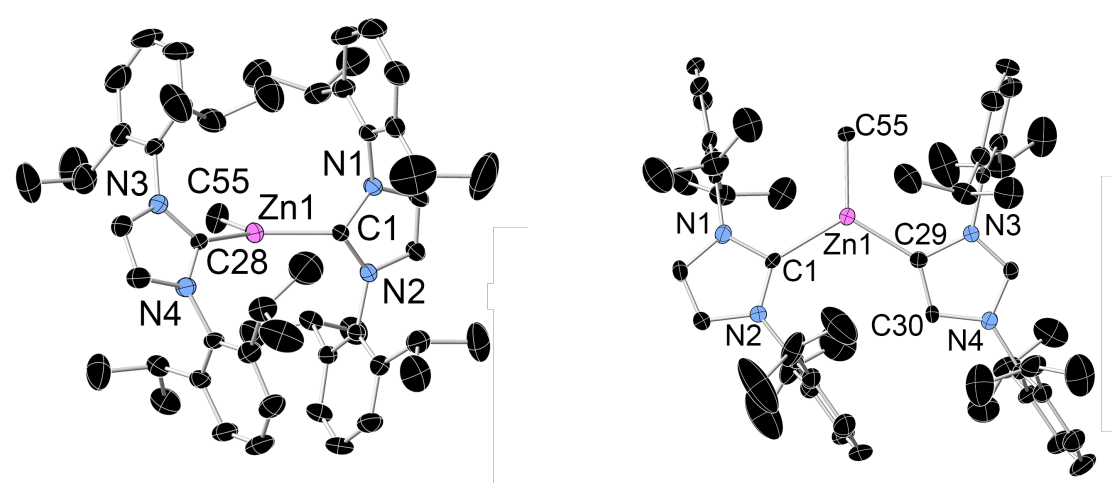

Figure 3. Molecular structures of bis-NHC Zn cationic isomers 13 (left) and 14 (right)

Unlike 13, cation 14 cleanly reacts with $\mathrm{CO}_{2}$ at $\mathrm{RT}$ through $\mathrm{CO}_{2}$ insertion into the $\mathrm{Zn}-\mathrm{Me}$ bond to produce [(IDipp)( $a$ IDipp $) \mathrm{Zn}-\mathrm{OAc}]^{+}$, the first instance of a well-characterized product from $\mathrm{CO}_{2}$ insertion into a $\mathrm{Zn}$-alkyl bond. Species 14 also mediates $\mathrm{CO}_{2}$ hydrosilylation (using $\mathrm{H}$ $\mathrm{Si}(\mathrm{OEt})_{3}$ as a hydrosilane source) but, contrasting with the two-coordinate $\mathrm{Zn}(\mathrm{II})$ cations $\mathbf{1 1}$ and 12 (vide supra), the reduction catalysis stops at the first reduction formate product, i.e. $\mathrm{HCO}_{2} \mathrm{Si}(\mathrm{OEt})_{3}$, in line with a lower Lewis acidity for three-coordinate $\mathrm{Zn}$ species 14.

\section{NHC-supported Zn hydrides}

Over the past few years, NHC coordination to $\mathrm{Zn}(\mathrm{II})$ has led to significant advances on the characterization and reactivity studies of molecularly well-defined $\mathrm{Zn}-\mathrm{H}$ species, which are of interest as well-defined and soluble reduction agents. ${ }^{41}$ Thanks to NHC coordination, discrete molecular adducts of $\mathrm{ZnH}_{2}$ were first reported as $\left[\mathrm{NHC}-\mathrm{ZnH}_{2}\right]_{2}$ dimeric adducts (15, Scheme 13 and Figure 4) by reaction of IDipp/IMes and $\mathrm{ZnH}_{2} .{ }^{42}$ 


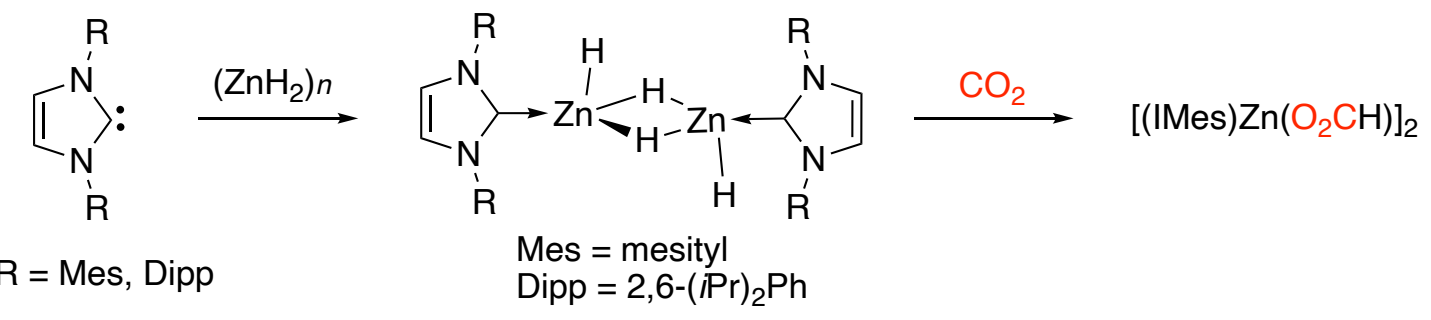

15

16

Scheme 13. Synthesis of NHC- $\mathrm{ZnH}_{2}$ adduct 15 and its insertion reactivity with $\mathrm{CO}_{2}$.

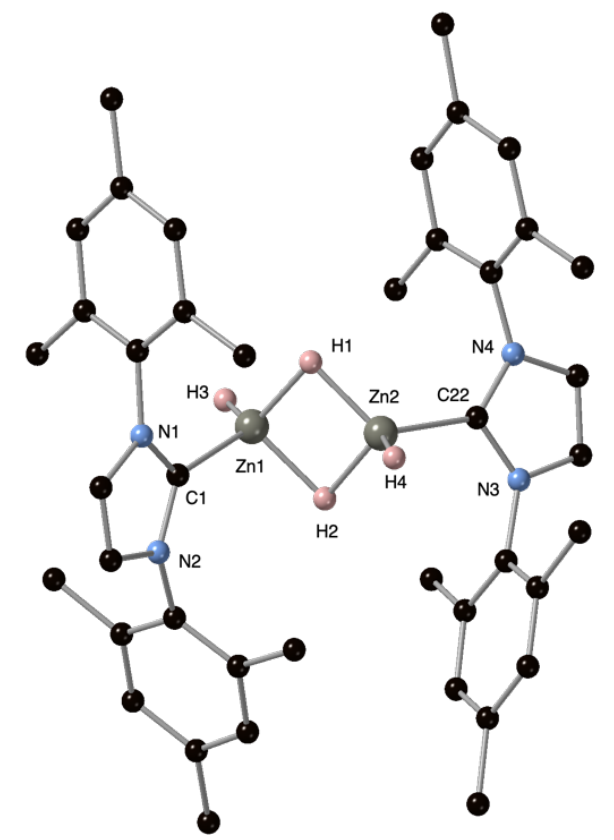

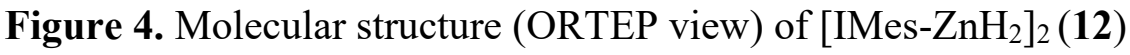

Species [IMes- $\left.\mathrm{ZnH}_{2}\right]_{2}$ readily reduces $\mathrm{CO}_{2}$ under mild conditions through $\mathrm{CO}_{2}$ insertion in the $\mathrm{Zn}-\mathrm{H}$ bonds to quantitatively afford the formate insertion product [(IMes) $\left.\mathrm{Zn}\left(\mathrm{O}_{2} \mathrm{CH}\right)_{2}\right]_{2}$ (16, Scheme 13). ${ }^{42,43}$ Adduct 15 is also a highly effective catalyst for the catalytic dehydrogenative methanolysis of hydrosilanes to silylether products.

Monomeric (NHC)Zn-H species are also viable species as demonstrated by the preparation of complex 17 (Scheme 14) through hydrogenation of zincocene $\left[\mathrm{Cp}^{*}{ }_{2} \mathrm{Zn}\right](\mathrm{Cp} *=$ pentamethylcyclopentadienyl) with $\mathrm{H}_{2}(68 \mathrm{bar})$ in the presence of SIMes. ${ }^{44}$ The $\mathrm{Zn}-\mathrm{H}$ species 
17 may be involved in Zn-catalyzed imine hydrogenation catalysis starting from a $\left[\mathrm{Cp}_{2} \mathrm{Zn}\right] / \mathrm{NHC}$ mixture as pre-catalyst. ${ }^{44}$

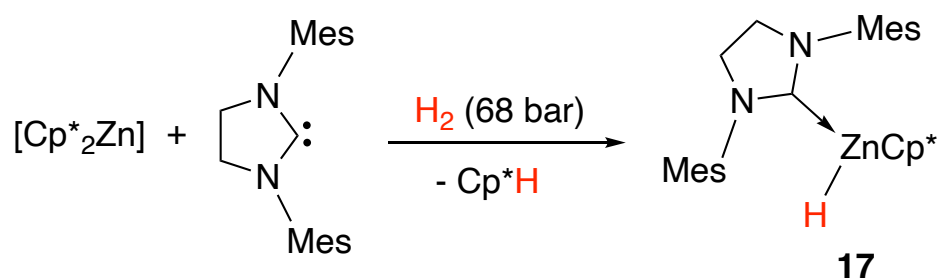

Scheme 14. Synthesis NHC-Zn hydride species 17 through hydrogenation of [Cp* $\left.{ }_{2} \mathrm{Zn}\right]$ in the presence of carbene SIMes.

The ability of NHCs to stabilize reactive Zn-based moieties was further evidenced by the recent synthesis and characterization of a monomeric NHC-supported $\mathrm{Zn}-\mathrm{H}$ cation $\left[(\mathrm{IDipp}) \mathrm{Zn}(\mathrm{H})(\mathrm{DMAP})_{2}\right]^{+}(\mathbf{1 8}, \mathrm{DMAP}=$ dimethylaminopyridine, Scheme 15 and Figure 5), the first instance of a molecularly well-defined $\mathrm{Zn}-\mathrm{H}$ cation, via reaction of MeOTf with neutral precursor [(IDipp) $\left.\mathrm{ZnH}_{2}\right]_{2}$ in the presence of DMAP. ${ }^{45}$ Dimer $\left[(\mathrm{IMes}) \mathrm{ZnH}_{2}\right]_{2}$ may also be ionized with $\left[\mathrm{PhMe}_{2} \mathrm{NH}\right]\left[\mathrm{BPh}_{4}\right]$ in the presence of THF to trinuclear $\mathrm{Zn}-\mathrm{H}$ dication 19 (Scheme $15) .{ }^{46}$<smiles>[R]N1C=CN([R])C1[Z17]([H])([H])[Z10]([H])([H])C1N([R])C=CN1[R]</smiles>

$R=$ Mes, Dipp

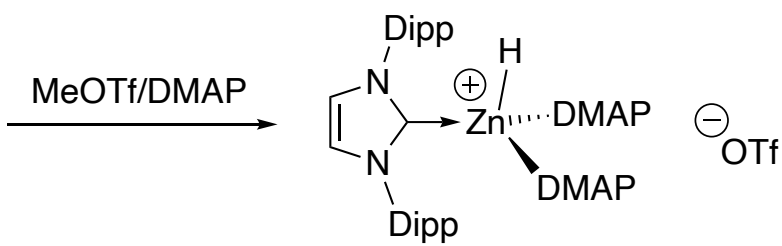

18

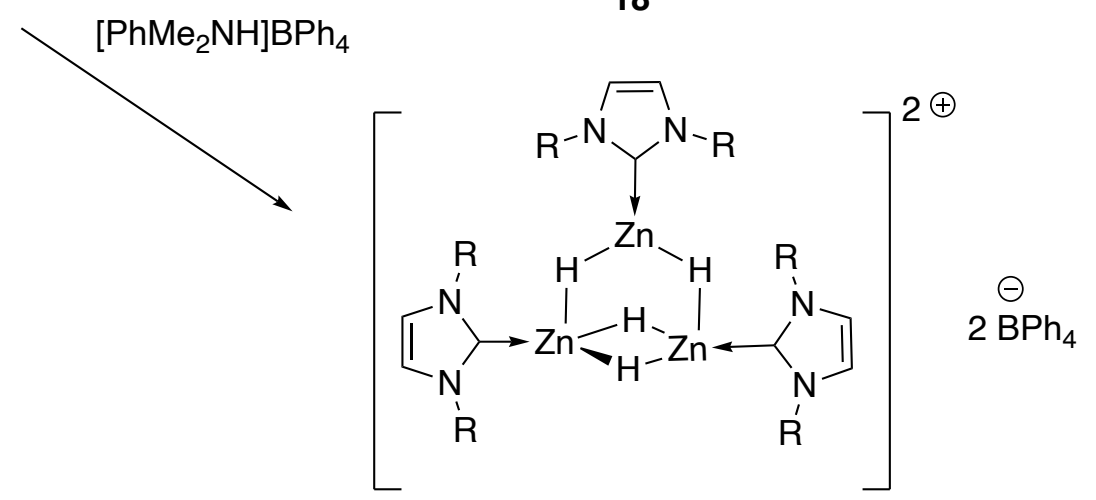

19

Scheme 15. Synthesis of NHC-supported Zn-H cations 18 and 19. 


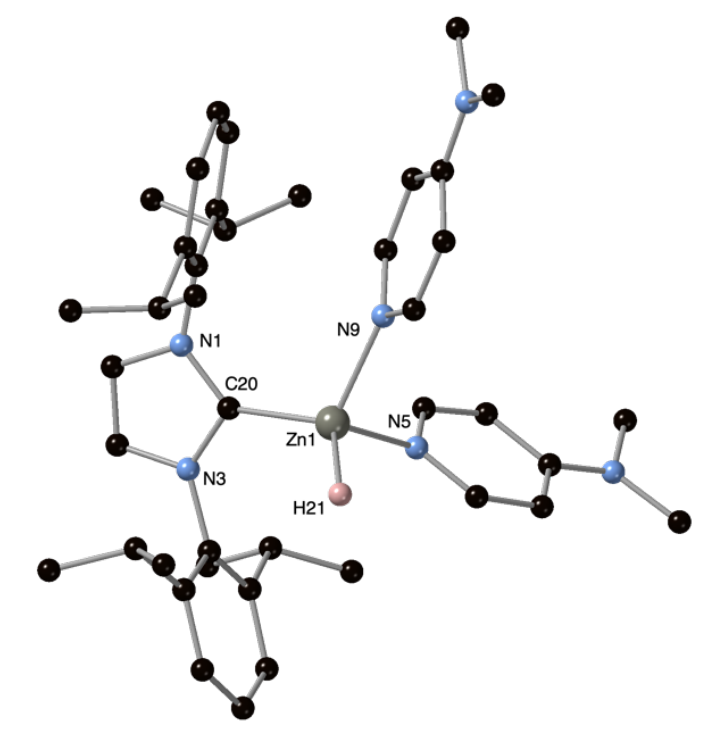

Figure 5. Molecular structure (ORTEP view) of cation $\left[(\mathrm{IDipp}) \mathrm{Zn}(\mathrm{H})(\mathrm{DMAP})_{2}\right]^{+}$(18).

These electrophilic $\mathrm{Zn}-\mathrm{H}$ cations may be used as catalysts for carbonyls and nitriles reduction under mild conditions, with insertion of the $\mathrm{C}=\mathrm{X}(\mathrm{X}=\mathrm{O}, \mathrm{N})$ group into the $\mathrm{Zn}-\mathrm{H}$ bond as the key reduction step. For instance, cation $19(1 \mathrm{~mol} \%)$ catalyzes $\mathrm{CO}_{2}$ reduction (60 ${ }^{\circ} \mathrm{C}, 40$ bar of $\left.\mathrm{CO}_{2}\right)$ to form $\mathrm{HCO}_{2} \mathrm{Si}(\mathrm{OEt})_{3}$ as the major product $(>80 \%)$, while it mediates nitriles mono-hydrosilylation catalysis (to $N$-silylated imine products) at room temperature. Both cations 18 and 19 are highly efficient hydrosilylation catalysts of ketones (to the corresponding silyl ether products) at room temperature using down to $0.1 \mathrm{~mol} \%$ of $\mathrm{Zn}$ catalyst and TOFs up to $475 \mathrm{~h}^{-1} \cdot{ }^{45,46}$

The Zn-H ion pair [(7Dipp)Zn(H)][NTf 2$]$ (20, 7Dipp = 1,3-bis(2,6-diisopropylphenyl)4,5,6,7-tetrahydro-1H-1,3-diazepin-3-ium-2-ide; Scheme 16), in which the cationic $\mathrm{Zn}(\mathrm{II})$ center is supported by a more sterically protecting 7-membered ring NHC ligand (vs. classical 5-membered ring NHCs), was recently synthesized by a $\sigma$-bond $\mathrm{Zn}-\mathrm{C} / \mathrm{H}-\mathrm{B}$ metathesis reaction, between [(7Dipp)Zn(Ph)][NTf 2 and pinacolborane (HBpin). ${ }^{47,48}$ Ion pair 20 readily dissociates in the presence of THF to afford a $\mathrm{Zn}-\mathrm{THF}$ cationic adduct as a dissociated $\left[\mathrm{NTf}_{2}\right]^{-}$salt (21, Scheme 16). 


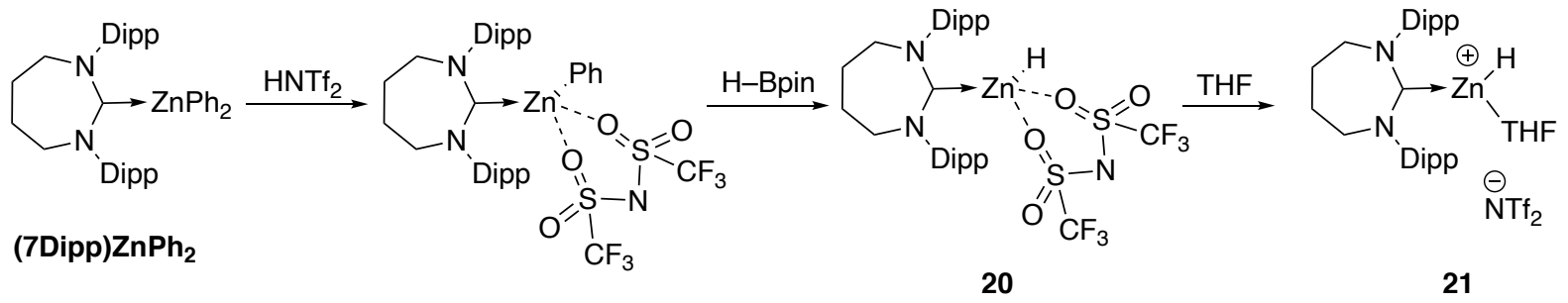

Scheme 16. Synthesis of the NHC-stabilized Zn-H compounds 20 and 21.

Interestingly, compound $\mathbf{2 0}$ was successfully used in alkyne dehydroboration and alkynyl boronic esters hydroboration catalysis (Scheme 17). Thorough experimental and computational studies of these catalysis support the mechanistic proposal depicted in Scheme 17 , in which $\sigma$-bond $\mathrm{Zn}-\mathrm{C} / \mathrm{H}-\mathrm{B}$ metathesis and hydrozincation of the alkynyl dehydroboration product are two crucial reaction steps for these catalytic processes to occur.

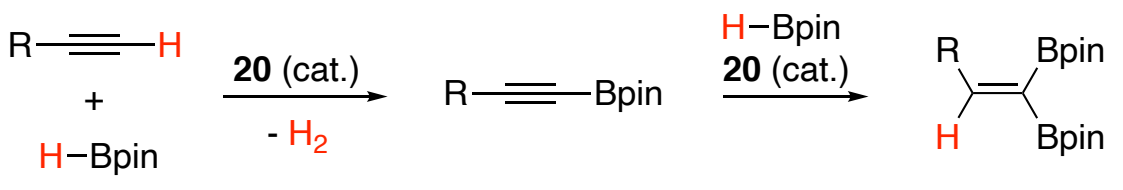

\section{Proposed mechanism}

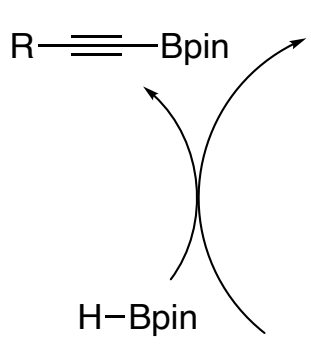

20

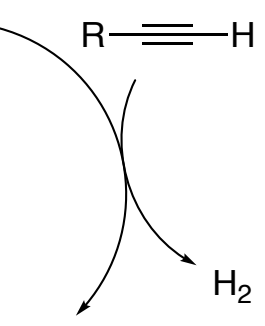

Dipp

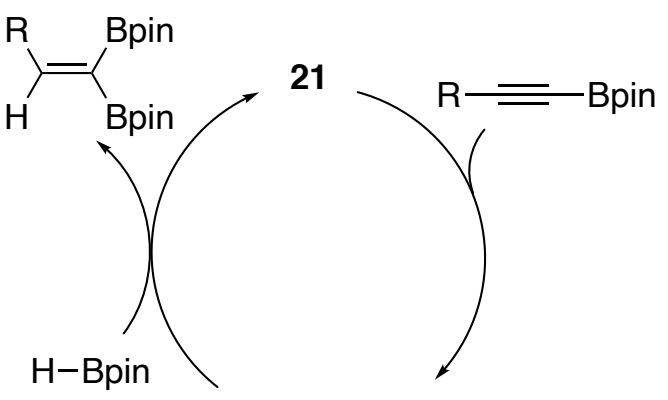

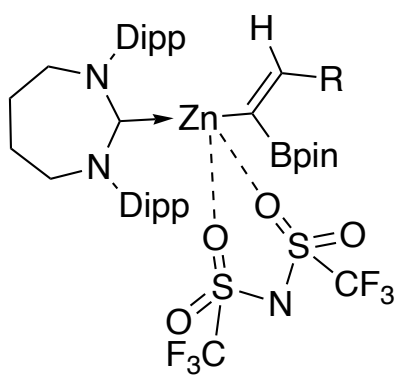

Scheme 17. Sequential alkyne dehydroboration and hydroboration catalysis mediated by NHCZn species $\mathbf{2 0}$ and the associated mechanism. 
It is important to note that the steric protection of $\mathrm{Zn}(\mathrm{II})$ provided by carbene 7Dipp provides an enhanced stability, which appears to be crucial for an effective catalysis under the reaction conditions. As a comparison, under identical reaction conditions, using IDipp instead 7Dipp for coordination to $\mathrm{Zn}$ (II) only led to marginal catalytic activity due to decomposition of the $\mathrm{Zn}$ catalyst. The limited stability the NHC-Zn moiety under hydroboration conditions was evidenced by the formation of the NHC-ring-opened product 22 (Scheme 18) from the reaction between [(7Dipp) $\left.\mathrm{ZnPh}_{2}\right]$ with 2 equiv $\mathrm{HB}(\mathrm{pin})$.

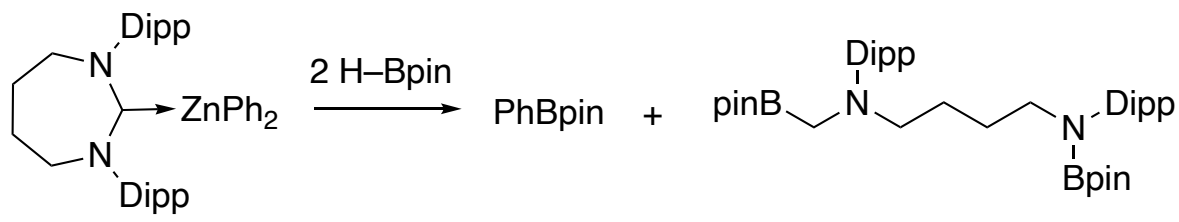

22

Scheme 18. Reaction of $\mathrm{H}-\mathrm{Bpin}$ with adduct [(7Dipp) $\mathrm{ZnPh}_{2}$ ]

\section{CAAC-supported and diamido-carbene-supported $\mathrm{Zn}$ species}

Cyclic Alkyl Amino Carbene (CAAC) ligands are NHCs displaying stronger $\sigma$-donating and $\pi$-accepting properties compared to classical Arduengo-type NHCs. As such, CAACs have drawn growing attention over the past few years due to their unique ability for the stabilization of various organometallic moieties, most notably low-valent metal centers, and the fact that CAAC metal/heteroelement species may display distinct reactivity relative to classical NHCstabilized analogues..$^{49,50}$

CAAC-supported $\mathrm{Zn}(\mathrm{II})$ species have been little explored to date but the couple of reports on the subject led to novel reactivity in organozinc chemistry. Thus, species $(\mathrm{CAAC}) \mathrm{ZnCl}_{2} \quad(\mathbf{2 3}, \quad \mathrm{CAAC}=1$-[2,6-bis(1-methylethyl)phenyl]-3,3,5,5-tetramethyl-2pyrrolidinylidene, Scheme 19), a thermally stable adduct, may be reduced to afford an unprecedented singlet biradicaloid Zn(II) species, (CAAC)Zn (24, Scheme 19), in which each former carbene center now bears one electron. ${ }^{51}$ Reaction of adduct $\mathbf{2 3}$ with the hydride reagent 
$\mathrm{LiB}(\sec \mathrm{Bu})_{3} \mathrm{H}$ yielded the $(\mathrm{CAAC}-\mathrm{H})_{2} \mathrm{Zn}$ complex 25 (Scheme 19), in line with an electrophilic $\mathrm{C}_{\mathrm{CAAC}}$ carbene center. The diradicaloid species 24 reacts rapidly with $\mathrm{CO}_{2}$ at low temperature to afford zwitterion CAAC- $\mathrm{CO}_{2}(\mathbf{2 6}$, Scheme 19), contrasting with the typical absence of reaction between neutral $\mathrm{ZnR}_{2}$ species and $\mathrm{CO}_{2}$ under such conditions.

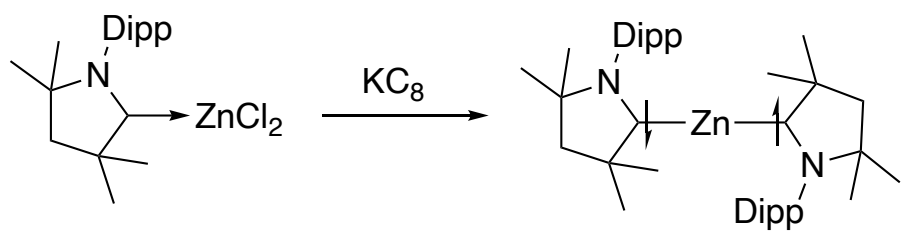

23

24
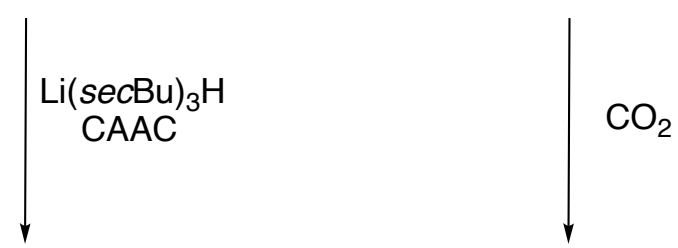

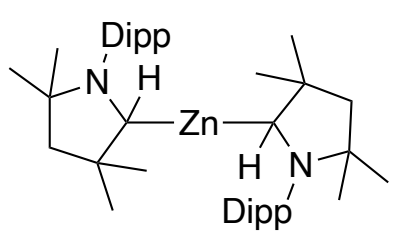

25

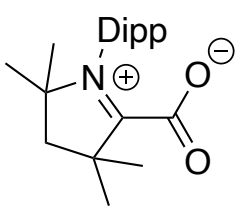

26

Scheme 19. Studied reactivity of adduct [(CAAC) $\left.\mathrm{ZnCl}_{2}\right] 23$.

The reactivity of CAAC carbene was also studied with simple $\mathrm{ZnR}_{2}$ organometallics such as $\mathrm{ZnMe}_{2}\left(\right.$ Scheme 20). ${ }^{52}$ Unlike classical $(\mathrm{NHC}) \mathrm{ZnR}_{2}$ adducts $(\mathrm{R}=$ alkyl), which are thermally stable and robust entities, ${ }^{19,22,38}\left[(\mathrm{CAAC}) \mathrm{ZnMe}_{2}\right]$ adduct 27 is thermally unstable above $-40{ }^{\circ} \mathrm{C}$ in solution and readily undergo carbene insertion into one of the $\mathrm{Zn}-\mathrm{Me}$ bonds to produce $\mathbf{2 8}$ (Scheme 20, Figure 6). The instability of adduct $\mathbf{2 7}$ and its transformation to $\mathbf{2 8}$ reflect the more electrophilic character of the carbene center in CAAC vs. Arduengo-type NHCs. 


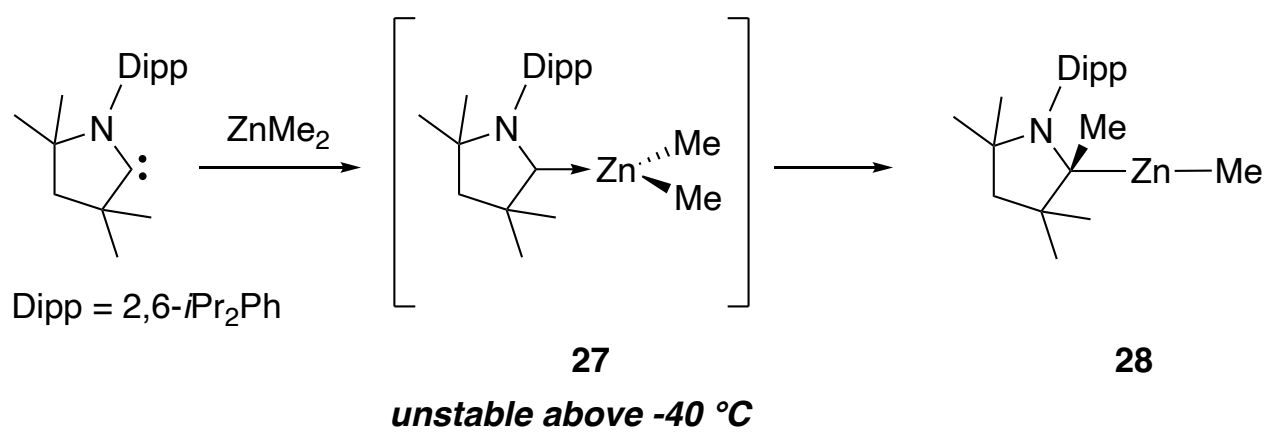

Scheme 20. CAAC carbene insertion reactivity into a Zn-alkyl bond.

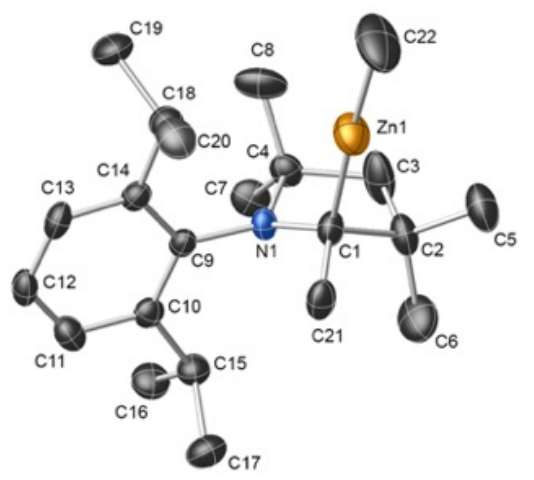

Figure 6. Molecular structure (ORTEP view) of insertion product 28.

Despite the thermal instability of neutral adduct $\mathbf{2 7}$, it may nevertheless be converted to robust two-coordinate CAAC-supported $\mathrm{Zn}(\mathrm{II})$ organocations of the type $[(\mathrm{CAAC}) \mathrm{Zn}-\mathrm{R}]^{+}(\mathrm{R}$ $=$ alkyl, aryl; 29 and 30, Scheme 21).

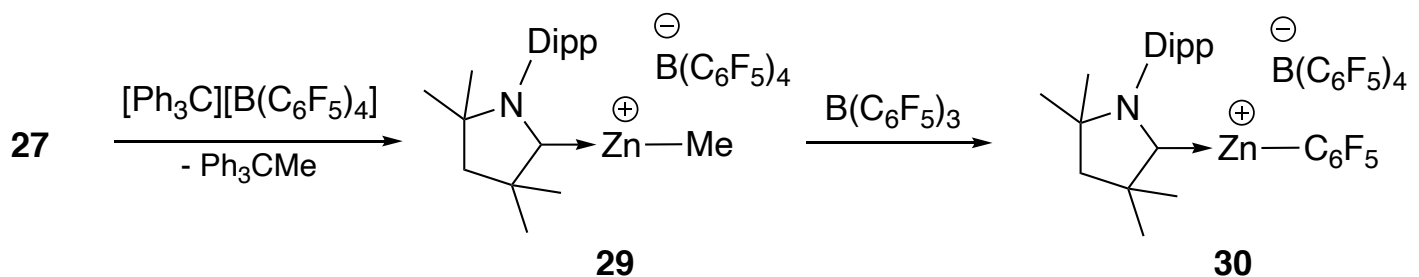

Scheme 21. Synthesis of CAAC-supported two-coordinate $\mathrm{Zn}(\mathrm{II})$ cations 29 and $\mathbf{3 0 .}$

As estimated from DFT calculations, the LUMO energy level of [(CAAC) $\left.\mathrm{Zn}-\mathrm{C}_{6} \mathrm{~F}_{5}\right]^{+}$ species is significantly lower than that of cation [(IDipp) $\left.\mathrm{Zn}-\mathrm{C}_{6} \mathrm{~F}_{5}\right]^{+}$(Figure 7), which is due to 
the higher $\pi$-accepting properties of the CAAC carbene. The latter may in principle lead to more reactive $[(\mathrm{CAAC}) \mathrm{Zn}-\mathrm{R}]^{+}$electrophiles provided the reactivity of such $\mathrm{Zn}(\mathrm{II})$ cations is, at least to some extent, under orbital control. Yet, both $\left[(\mathrm{CAAC}) \mathrm{Zn}-\mathrm{C}_{6} \mathrm{~F}_{5}\right]^{+}$and [(IDipp)Zn$\left.\mathrm{C}_{6} \mathrm{~F}_{5}\right]^{+}$cations display similar activity in alkene and $\mathrm{CO}_{2}$ hydrosilylation catalysis, strongly suggesting that the reactivity of these cationic systems is only under charge control.
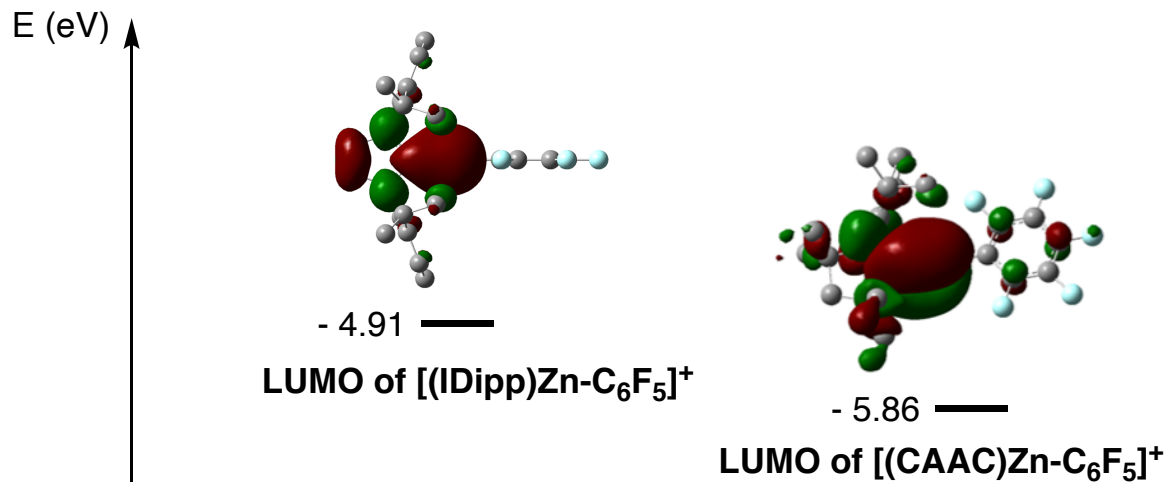

Figure 7. DFT-estimated LUMOs of $\left[(\text { IDipp }) \mathrm{Zn}-\mathrm{C}_{6} \mathrm{~F}_{5}\right]^{+}(\mathbf{1 2})$ and $\left[(\mathrm{CAAC}) \mathrm{Zn}-\mathrm{C}_{6} \mathrm{~F}_{5}\right]^{+}(\mathbf{3 0})$ cations

Due to the presence of carbonyl groups adjacent to the ring nitrogen atoms, diamido carbenes (DACs, see for instance MesDAC in Scheme 22; MesDAC $=1,3$-bis $(2,4,6-$ trimethylphenyl), tetrahydro-5,5-dimethyl-4,6-dioxo-pyrimidin-2-ylidene) constitute a recently developed class of NHCs also displaying enhanced $\pi$-accepting properties and a more electrophilic carbene center when compared to classical diamino NHCs. ${ }^{53}$ DACs have primarily been used as ligands for the stabilization of various late transition metal centers. ${ }^{54}$ One example of DAC-supported $\mathrm{Zn}(\mathrm{II})$ species is known to date, [(MesDAC) $\left.\mathrm{ZnR}_{2}\right]\left(\mathbf{3 1}\right.$, Scheme 22) ${ }^{55}$ Akin to CAAC-Zn chemistry discussed above, adduct $\mathbf{3 1}$ is unstable at RT (in solution) and undergoes carbene insertion into one the $\mathrm{Zn}$-alkyl bond to yield product 32, as unambiguously confirmed by X-ray crystallographic analysis. Such reactivity clearly arises from the electrophilic character of the $\mathrm{C}_{\text {carbene }}$ center in $\mathbf{3 1}$. 
<smiles>CN1CN(C)C(=O)C(C)(C)C1=O</smiles>

MesDAC<smiles>[R]CC(C)C</smiles>

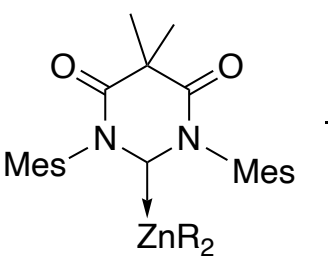

31

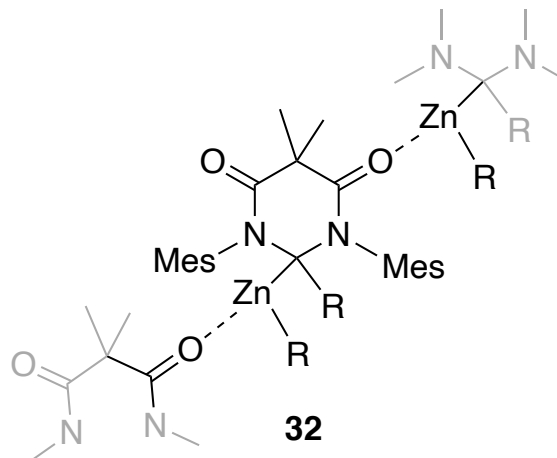

32

Scheme 22. Di-amido-carbene-supported $\mathrm{Zn}$ (II) species and derived carbene insertion reactivity.

\section{Conclusion}

Over the past five to ten years, NHC-stabilized $\mathrm{Zn}$ complexes have undoubtedly contributed to fundamental progress and applications of $\mathrm{Zn}$ organometallics. The extra-ordinary ability of NHCs to stabilize $\mathrm{Zn}$ (II) has permitted the stabilization and characterization of unprecedented $\mathrm{Zn}$ (II) structural motifs, most notably two-coordinated $\mathrm{Zn}$ (II) organocations and molecularly well-defined $\mathrm{Zn}$ hydrides. In addition to their fundamental interest, these two classes of compounds have led to novel catalytic applications, in particular hydrosilylation catalysis of small molecules of interest $\left(\mathrm{CO}_{2}\right.$, carbonyls, alkenes, alkynes, imines, nitriles) under mild conditions. Further, thanks to their straightforward and superior stability $v s$. most adducts of the type $\left[(\mathrm{L}) \mathrm{ZnX}_{2}\right]$, more classical $\left[(\mathrm{NHC}) \mathrm{ZnX}_{2}\right]$ species have also demonstrated their suitability for various catalytic processes ranging from $\mathrm{CO}_{2}$ reductive amination, crosscoupling catalysis, alkyne dehydroboration, alkynyl boronic ester hydroboration, imine hydrogenation to enantioselective alkylation reactions. Given the readily synthetic availability of numerous NHC scaffolds with tailored electronic and steric properties, NHC-Zn species hold great potential in the coming years for fundamental developments in organometallic chemistry and the mediation of various catalytic processes. 
Acknowledgments. The authors thank the CNRS and the University of Strasbourg for financial support. 


\section{References}

${ }^{1}$ S. P. Nolan, $2006 \mathrm{~N}$-Heterocyclic Carbenes in Synthesis, Wiley-VCH, Weinheim.

2 S. Díez-González, $2011 \mathrm{~N}$-Heterocyclic Carbenes, From Laboratories Curiosities to Efficient Synthetic Tools, RSC Catalysis Series, RSC Publishing, Cambridge.

${ }^{3}$ W. A. Herrmann, C. Köcher, Angew. Chem. Int. Ed. 1997, 36, 2162-2187.

${ }^{4}$ R. H. Crabtree, Coord. Chem. Rev. 2013, 257, 755-766.

${ }^{5}$ A. J. Arduengo III, Acc. Chem. Res. 1999, 32, 913-921.

${ }^{6}$ D. Bourissou, O. Guerret, F. P. Gabbaï, G. Bertrand, Chem. Rev. 2000, 100, 39-92.

${ }^{7}$ D. J. Nelson, S. P. Nolan, Chem. Soc. Rev. 2013, 42, 6723-6753.

${ }^{8}$ L. Benhamou, E. Chardon, G. Lavigne, S. Bellemin-Laponnaz, V. César, Chem. Rev. 2011, $111,2705-2733$.

${ }^{9}$ S. T. Liddle, I. S. Edworthy, P. L. Arnold, Chem. Soc. Rev. 2007, 36, 1732-1744.

${ }^{10}$ S. Bellemin-Laponnaz, S. Dagorne, Chem. Rev. 2014, 114, 8747-8774.

${ }^{11}$ C. Fliedel, G. Schnee, T. Avilés, S. Dagorne, Coord. Chem. Rev. 2014, 275, 63-86.

${ }^{12}$ S. Khan, H. W. Roesky, Chem. - Eur. J. 2019, 25, 1636-1648.

${ }^{13}$ Y. Wang, G. H. Robinson, Dalton Trans. 2012, 41, 337-345.

${ }^{14}$ V. Nesterov, D. Reiter, P. Bag, P. Frisch, R. Holzner, A. Porzelt, S. Inoue, Chem. Rev. 2018, $118,9678-9842$.

${ }^{15}$ A. Doddi, M. Peters, M. Tamm, Chem. Rev. 2019, 119, 6994-7112.

${ }^{16}$ E. Peris, Chem. Rev. 2018, 118, 9988-10031.

17 T. Hirose, K. Kodama, in Comprehensive Organic Synthesis, eds. P. Knochel, G. A. Molander, Elsevier B. V., Amsterdam, $2^{\text {nd }}$ edition, 2014, Vol. 1, pp 204-266.

18 S. Enthaler, ACS Catal. 2013, 3, 150-158.

${ }^{19}$ A. J. Arduengo, H. V. R. Dias, F. Davidson, R. L. Harlow, J. Organomet. Chem. 1993, 462, $13-18$.

${ }^{20}$ S. Budagumpi, S. Endud, Organometallics 2013, 32, 1537-1562.

${ }^{21}$ S. Dagorne, Synthesis 2018, 50, 3662-3670.

${ }^{22}$ G. Schnee, C. Fliedel, T. Avilés, S. Dagorne, Eur. J. Inorg. Chem. 2013, 2013, 3699-3709.

${ }^{23}$ J. B. Waters, R. S. P. Turbervill, J. M. Goicoechea, Organometallics 2013, 32, 5190.

${ }^{24}$ D. R. Armstrong, S. E. Baillie, V. L. Blair, N. G. Chabloz, J. Diez, J. Garcia-Alvarez, A. R. Kennedy, S. D. Robertson, E. Hevia, Chem. Sci. 2013, 4, 4259-4266. 
${ }^{25}$ K. Naktode, S. Anga, R. K. Kottalanka, H. P. Nayek, T. K. Panda, J. Coord. Chem. 2014, 67, $236-248$.

${ }^{26}$ L. R. Collins, L. A. Moffat, M. F. Mahon, M. D. Jones, M. K. Whittlesey, Polyhedron 2016, $103,121-125$.

${ }^{27}$ C. Fliedel, D. Vila-Viçosa, M. J. Calhorda, S. Dagorne, T. Avilés, ChemCatChem 2014, 6, $1357-1367$.

${ }^{28}$ C. Fliedel, S. Mameri, S. Dagorne, T. Avilés, Appl. Organomet. Chem. 2014, 28, 504-511.

${ }^{29}$ S. Slomkowski, S. Penczek, A. Duda, Polym. Adv. Technol. 2014, 25, 436-447.

${ }^{30}$ P. Gallezot, Green Chem. 2007, 9, 295-302.

${ }^{31}$ K. Fukushima, Biomater. Sci. 2016, 4, 9-24.

32 O. Jacquet, X. Frogneux, C. Das Neves Gomes, T. Cantat, Chem. Sci. 2013, 4, 2127-2131.

${ }^{33}$ P. Jochmann, D. W. Stephan, Organometallics 2013, 32, 7503-7508.

${ }^{34}$ S. K. Bose, K. Fucke, L. Liu, P. G. Steel, T. B. Marder, Angew. Chem. Int. Ed. 2014, 53, 1799-1803.

${ }^{35}$ S. K. Bose, T. B. Marder, Org. Lett. 2014, 16, 4562-4565.

${ }^{36}$ S. Xu, W. C. Everett, A. Ellern, T. L. Windus, A. D. Sadow, Dalton Trans. 2014, 43, 1436814376.

${ }^{37}$ Y. Lee, B. Li, A. H. Hoveyda, J. Am. Chem. Soc. 2009, 131, 11625-11633.

${ }^{38}$ D. Specklin, F. Hild, C. Fliedel, C. Gourlaouen, L. F. Veiros, S. Dagorne, Chem.-Eur. J. 2017, 23, 15908-15912.

${ }^{39}$ M. Oestreich, J. Hermeke, J. Mohr, Chem. Soc. Rev. 2015, 44, 2202-2220.

${ }^{40}$ D. Specklin, C. Fliedel, C. Gourlaouen, J.-C. Bruyere, T. Avilés, C. Boudon, L. Ruhlmann, S. Dagorne, Chem.-Eur. J. 2017, 23, 5509-5519.

${ }^{41}$ A.-K. Wiegand, A. Rit, J. Okuda, Coord. Chem. Rev. 2016, 314, 71-82.

42 A. Rit, T. P. Spaniol, L. Maron, Jun. Okuda, Angew. Chem. Int. Ed. 2013, 52, 4664-4667.

${ }^{43}$ A. Rit, T. P. Spaniol, L. Maron, J. Okuda, Organometallics 2014, 33, 2039-2047.

${ }^{44}$ P. Jochmann, D. W. Stephan, Angew. Chem. Int. Ed. Engl. 2013, 52, 9831-9835.

${ }^{45}$ P. A. Lummis, M. R. Momeni, M. W. Lui, R. McDonald, M. J. Ferguson, M. Miskolzie, A. Brown, E. Rivard, Angew. Chem. Int. Ed. 2014, 53, 9347-9351.

${ }^{46}$ Rit, A.; Zannardi, A.; Spaniol, T. P.; Maron, L.; Okuda, J. Angew. Chem. Int. Ed. 2014, 53, 13273.

${ }^{47}$ R. J. Procter, M. Uzelac, J. Cid, P. J. Rushworth, M. J. Ingleson, ACS Catal. 2019, 9, 57605771.

${ }^{48}$ M. Uzelac, K. Yuan, M. J. Ingleson, Organometallics 2020, 39, 1332-1338. 
${ }^{49}$ B. Rao, H. Tang, X. Zeng, L. Liu, M. Melaimi, G. Bertrand, Angew. Chem. Int. Ed. 2015, 54, 14915-14919.

${ }^{50}$ M. Melaimi, R. Jazzar, M. Soleilhavoup, G. Bertrand, Angew. Chem. Int. Ed. 2017, 56, 10046-10068.

${ }^{51}$ A. P. Singh, P. P. Samuel, H. W. Roesky, M. C. Schwarzer, G. Frenking, N. S. Sidhu, Birger. Dittrich, J. Am. Chem. Soc. 2013, 135, 7324-7329.

52 J.-C. Bruyere, D. Specklin, C. Gourlaouen, R. Lapenta, L. F. Veiros, A. Grassi, S. Milione, L. Ruhlmann, C. Boudon, S. Dagorne, Chem. -Eur. J. 2019, 25, 8061-8069.

53 J. P. Moerdyk, D. Schilter, C. W. Bielawski, Acc. Chem. Res. 2016, 49, 1458-1468.

${ }^{54}$ T. W. Hudnall, C. W. Bielawski, J. Am. Chem. Soc. 2009, 131, 16039-16041.

${ }^{55}$ L. R. Collins, G. Hierlmeier, M. F. Mahon, I. M. Riddlestone, M. K. Whittlesey, Chem. Eur. J. 2015, 21, 3215-3218. 


\section{Biographical information}

\section{David Specklin}

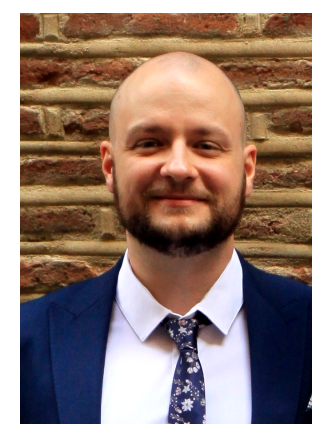

David Specklin obtained his PhD in Chemistry from the University of Strasbourg (FR) in 2014. He then joined the group of Dr. Samuel Dagorne (University of Strasbourg) as Post-Doctoral research associate for three years during which he focused on the chemistry of zinc \& group 13 metal complexes. In 2018, he joined Dr. Antoine Simonneau group to continue his postdoctoral studies at Laboratoire de Chimie de Coordination (CNRS, Toulouse, FR) working with lowvalent metal complexes for dinitrogen activation.

\section{Christophe Fliedel}

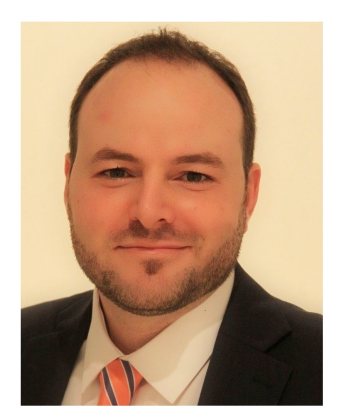

Christophe Fliedel received his Ph.D. from the University of Strasbourg (France) in 2010 under the supervision of Dr. Pierre Braunstein. He then moved to the New University of Lisbon (Portugal), where he was awarded a postdoctoral fellowship from the Fundação para a Ciência e a Tecnologia (FCT, Portugal), to conduct research in the group of Prof. Teresa Avilés (Universidade Nova de Lisboa) and in collaboration with Dr. Samuel Dagorne (Université de Strasbourg). He completed his habilitation in 2015 and joined, early in 2016, the CNRS as an associate researcher at the Laboratoire de Chimie de Coordination (LCC) in Toulouse (France). His research interests are mainly focused on organometallic and coordination chemistry for applications in ring-opening and radical polymerization techniques. 


\section{Samuel Dagorne}

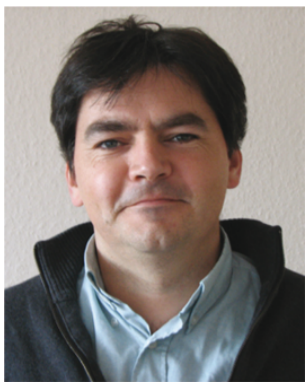

Samuel Dagorne obtained his undergraduate degree at the University of Rennes (France) in 1994. In 1995, he joined the group of Professor Richard F. Jordan at the University of Iowa (Iowa City, USA) and graduated with a Ph.D in organometallic chemistry in 1999. He then joined Professor Richard R. Schrock's group (MIT, USA) as a post-doc. Back in France, he joined the C.N.R.S. in 2000 and is currently a senior researcher/team leader at the Institute of Chemistry of Strasbourg (University of Strasbourg, France). His research interests include the synthesis, reactivity and use in catalysis of oxophilic organometallic complexes. 